\title{
STATUS AKREDITASI RUMAH SAKIT SEBAGAI UPAYA MENDORONG PENINGKATAN KESELAMATAN PASIEN
}

\author{
Elisa Claudia Simanjuntak / 181101114 \\ elclaudia02@gmail.com
}

\begin{abstract}
ABSTRAK
Latar Belakang : Status akreditasi dapat dikatakan sebagai pengakuan bahwa rumah sakit sudah memenuhi standar. Banyak orang yang berasumsi bahwa rumah sakit yang status akreditasinya sudah baik atau sudah mendapat pengakuan, sudah pasti pelayanannya baik dan mengutamakan keselamatan pasien.

Tujuan : Tujuan penulisan kajian ini adalah untuk mengetahui hubungan antara status akreditasi rumah sakit dengan keselamatan pasien.

Metode : Metode yang digunakan dalam kajian ini adalah literature review, yaitu dengan cara menganalisis, mengeksplorasi serta mengkaji bebas jurnal dan buku teks yang membahas tentang hubungan status akreditasi rumah sakit dengan keselamatan pasien.

Hasil : Status akreditasi dapat menjadi acuan bagi rumah sakit untuk meningkatkan keselamatan pasien.

Pembahasan : Akreditasi rumah sakit memberikan panduan implementasi standar manajemen mutu untuk mengurangi Insiden Keselamatan Pasien (IKP). Status akreditasi merupakan pengakuan bahwa rumah sakit sudah memenuhi standar dengan status akreditasi paripurna.

Kata Kunci : Status Akreditasi, Rumah Sakit, Keselamatan Pasien.
\end{abstract}




\section{Latar Belakang}

Status akreditasi rumah sakit merupakan suatu pengakuan yang diberikan kepada rumah sakit sesuai dengan standar pelayanannya. Dengan adanya akreditasi, pelayanan kesehatan yang diberikan rumah sakit dapat dipertanggungjawabkan.

Semakin berkembangnya zaman, tuntutan kualitas atau mutu pelayanan kesehatan juga meningkat. Hal ini ditandai dengan berbagai kritikan tentang ketidakpuasan terhadap pelavanan rumah sakit yang disampaikan melalui jalur hukum. Oleh karena itu, rumah sakit perlu berbenah memperbaiki atau meningkatkan mutu pelayanannya.

Salah satu indikator pelayanan rumah sakit yang bermutu yaitu keselamatan pasien. Pelayanan kesehatan yang baik akan memberikan jaminan keselamatan kepada pasiennya. Program keselamatan pasien yang dilakukan dengan baik, dapat memberikan gambaran tentang mutu pelayanan kesehatan yang diberikan. Salah satu indikator untuk menilai mutu pelayanan kesehatan di rumah sakit adalah dengan cara meningkatkan penerapan keselamatan pasien.

\section{Tujuan}

Untuk mengetahui hubungan antara akreditasi rumah sakit dengan keselamatan pasien.

\section{Metode}

Metode yang digunakan dalam kajian ini adalah literature review, yaitu dengan cara menganalisis, mengeksplorasi serta mengkaji bebas jurnal dan buku teks yang membahas tentang akreditasi rumah sakit dan keselamatan pasien. Referensi berupa jurnal dan buku teks yang digunakan adalah sebanyak 14. Jurnal yang digunakan sebagai referensi dalam tulisan ini diterbitkan dalam kurun waktu 10 tahun terakhir.

\section{Hasil}

Status akreditasi rumah sakit sebaiknya dijadikan sebagai acuan untuk mendorong peningkatan keselamatan pasien. Status akreditasi rumah sakit memberikan gambaran tentang mutu pelayanan kesehatannya. Rumah sakit dengan mutu pelayanan yang baik, pasti akan memperhatikan setiap hal yang mempengaruhi status akreditasinya. Keselamatan pasien salah satunya, peningkatan nilai keselamatan pasien 
akan sangat dipengaruhi oleh status akreditasi rumah sakit.

\section{Pembahasan}

Status akreditasi merupakan sebuah acuan yang dapat mendorong rumah sakit untuk semakin meningkatkan mutu pelayanannya. Akreditasi mendorong perawat untuk lebih memperhatikan upaya keselamatan pasien di rumah sakit. Semakin baik akreditas sebuah rumah sakit, semakin besar juga keinginan dan tanggung jawab untuk memberikan pelayanan kesehatan dengan mutu terbaik.

Pada dasarnya tujuan utama akreditasi rumah sakit adalah agar kualitas pelayanan yang diberikan terintegrasi. Rumah sakit dengan status akreditasi yang baik, akan mendorong para pegawainya meningkatkan kesadaran akan keselamatan pasien. Oleh sebab itu dikatakan, bahwa status akreditasi akan mempengaruhi peningkatan terjadinya keselamtatan pasien.

\section{Penutup}

Status akreditasi merupakan suatu acuan bagi rumah sakit untuk menjalankan pelayanan kesehatan dengan baik.
Rumah sakit dengan status akreditasi yang baik, akan memperhatikan pelayanan kesehatan khususnya dibidang keselamatan pasien. Oleh sebab itu, maka dapat disimpulkan bahwa status akreditasi dapat memepengaruhi peningkatan keselamatan pasien.

\section{Referensi}

Azwar, A. Pengantar Administrasi Kesehatan edisi ketiga.2010. Jakarta:Binarupa Aksara.

Batubara, S. dkk. (2019). Hubungan Status Akreditasi Puskesmas Dengan Mutu Pelayanan di Kabupaten Simalungun. Jurnal UISU. 8(1): 1-12.

Ismainar, Hetty. (2015). Keselmatan Pasien di Rumah Sakit. Yogyakarta: Deepublish.

Nugroho, Sri H.P., Sujianto,U. (2014). Supervisi Kepala Ruang Model Proctor Untuk Meningkatkan Pelaksanaan Keselamatan Pasien. Jurnal Keperawatan Indonesia. 20(1): 56-64. Nugroho, Sri H.P., Sujianto,U. (2014). Supervisi Kepala Ruang Model Proctor Untuk Meningkatkan Pelaksanaan 
Keselamatan Pasien. Jurnal

Keperawatan Indonesia. 20(1): 56-64.

Putro, S. dkk. (2018). Apakah Status

Akreditasi Rumah Sakit Memberikan

Perbedaan Pemberian Obat yang Benar dan Keselamatan Pasien ?. Jurnal MKMI.14(4): 378-387.

Rivai, F., Sidin, A.I. (2016). Faktor

Yang berhubungan dengan implementasi keselamatan pasien di RSUD Ajjapponnge Soppeng Tahun 2015. Jurnal Kebijakan Kesehatan Indonesia. (5): 152-157.

Simamora, R. H. (2019). Buku Ajar Pelaksanaan Identifikasi Pasien. UWAIS:Inspirasi Indonesia.

Simamora, R. H. (2019). The influence Of Training Handover based SBAR Communication for improving patients Safety. Indian journal of public Health Reserch \& Development.

Simamora, R. H. (2019). Documentation of patient Identification into the Electronic System to improve the quality of nursing services. Internasional Journal of Scientific \& Technology Reasearch.
Utarini, A. \& Djasri, H. (2012). Keselamatan Pasien dan Mutu Pelayanan Kesehatan. Jurnal Manajemen Pelayanan Kesehatan. 159160.

Wawan, A dkk. 2010. Teori dan pengukuran Pengetahuan, Sikap, Perilaku Manusia. Yogyakarta : Nuha Medika Barat.

Yewen, M. R. dkk. (2018). Hubungan Antara Status Akreditasi Puskesmas Dengan Tingkat Kepuasan Pasien di Kota Sorong Provinsi Papua Barat. eJournal UNSRAT. 7(5).

Yulia, S., dkk. (2012). Peningkatan Pemahaman Perawat Pelaksana dalam Penerapan Keselamatan Pasien Melalui Pelatihan Keselamatan Kerja. Jurnal Keperawatan. 15(3): 185-192. 